\title{
Effects of extreme inflows on the water quality and phytoplankton of seven reservoirs in subtropical Australia
}

\author{
Catherine Leigh, ${ }^{1,2}$ Andrew Watkinson, ${ }^{3}$ and Michele A. Burford ${ }^{1} *$ \\ ${ }^{1}$ Australian Rivers Institute, Griffith University, Queensland, Australia \\ ${ }^{2}$ Irstea, Ur-Maly, Villeurbanne, France \\ ${ }^{3}$ Seqwater, Brisbane, Queensland, Australia \\ * Corresponding author email: m.burford@griffith.edu.au
}

The full text of this manuscript is published in Inland Waters, volume 5, pages 240-252, DOI: 10.5268/IW-5.3.814, and is available online at https://www.fba.org.uk/journals/

Short title: Extreme inflows and water quality in impounded rivers

\begin{abstract}
Differentiating the relative importance of catchments and reservoirs in driving water quality in impounded rivers is challenging because water quality reflects the integration of peak events (e.g., rainfall-driven inflows) and longer-term processes (e.g., sediment remineralization of nutrients). We examined water quality in several subtropical reservoirs following extreme summer rainfall and associated inflows to determine short- and longerterm implications in terms of reservoir vulnerability to poor water quality and blooms of cyanobacteria, as reflected by the Vulnerability Index (VI), a previously described index validated under low-flow conditions. The reservoir with the highest VI, Wivenhoe, had the highest concentrations of total suspended solids, phosphorus (total and dissolved inorganic fractions), and nitrate/nitrite following the event, whereas the reservoir with the lowest VI,
\end{abstract}


Cooloolabin, had the lowest concentrations. This suggests that vulnerability to poor water quality during major inflows is driven by suspended solids and nutrients, with the VI being a robust measure irrespective of inflow conditions. By contrast, phytoplankton-related measures, including cyanobacteria proportions, in Wivenhoe were not higher than in Cooloolabin, possibly due to reduced water residence times and increased light attenuation (shallower Secchi depth) preventing bloom establishment. This finding contrasts with lowflow summers when reservoirs with the highest phytoplankton biomass align with those with the highest VI and suggests that short-term vulnerability to poor water quality associated with peak events is not driven directly by phytoplankton. While inflows increase nutrients and suspended solids, biotic responses appear delayed, highlighting the challenges of linking catchment-derived nutrient loads to phytoplankton responses in event-driven systems.

Key words: algal bloom, cyanobacteria, extreme event, impoundment, nutrients, watershed

\section{Introduction}

Catchments degraded by human activities, including agriculture, mining, and urban development, increase the export of land-derived nitrogen $(\mathrm{N})$, phosphorus $(\mathrm{P})$, and sediment to receiving waters (Carpenter et al. 1998, Syvitski et al. 2005), particularly following heavy rainfall. As a result of sediment trapping by reservoirs, however, the modern, annual global sediment flux to the world's oceans is estimated to be lower than the prehuman flux (Syvitski et al. 2005). Globally, reservoirs are also typically sinks for N and P (Bosch and Allan 2008, Harrison et al. 2009, Burford et al. 2012).

Catchment-derived inputs to receiving waters promote eutrophication and are considered a key factor in the contemporary expansion of phytoplankton bloom incidence (Carpenter et al. 1998, Smith 2003, Schindler 2006, Carney 2009). Cyanobacterial blooms in 
particular have been linked to nutrient enrichment in receiving waters with long residence times and stratification (Xu et al. 2010, O’Neil et al. 2012, Romo et al. 2013), characteristics typified by many reservoirs. Several factors play roles in determining the composition and dynamics of phytoplankton assemblages, however, including catchment land use type, extent and intensity (McGregor and Fabbro 2000, Burford et al. 2007, Leigh et al. 2013), waterbody shape (Wetzel 2001), reservoir management, and water level fluctuations (Katsiapi et al. 2011, Zohary and Ostrovsky 2011), along with seasonality (e.g., warmer seasons marking growth periods) and climate-driven variation in river inflows (Harris and Baxter 1996, Davis and Koop 2006, O’Neil et al. 2012, Leigh et al. 2013).

In subtropical reservoirs, a range of summer phytoplankton and nutrient measures have been shown to correlate with both catchment and reservoir characteristics, specifically the percentage of cattle-grazing land cover (“rangelands”), reservoir volume, reservoir volume to catchment area ratio, reservoir shoreline to surface area ratio, and age since dam wall construction (Leigh et al. 2010a), reflecting relationships between land use, reservoir morphology, and reservoir water quality demonstrated in other parts of the world (e.g., Jones et al. 2004, Nielson et al. 2012). Together these characteristics can successfully predict, by way of a composite index, the comparative vulnerability of reservoirs to seasonal poor water quality and cyanobacterial blooms (Leigh et al. 2010a, 2010b). The incorporation of reservoir age into the vulnerability index (VI) is particularly useful because it allows reservoir vulnerability to be projected through time and the vulnerability of new or planned reservoirs to be compared against existing reservoirs. The potential effect on water quality of altered land use or infrastructure upgrades that change reservoir size and shape can also be projected. To our knowledge, however, the predictive ability of the VI has only been examined during low to average rainfall years (non-event periods). 
Subtropical and tropical regions can experience heavy rainfall during summer, providing an opportunity to differentiate the effects of peak events, such as reservoir inflows, and longer-term internal reservoir processes on water quality, and hence to assess the performance of the VI. In this study, we hypothesised that high rainfall and subsequent extreme summer inflows to reservoirs would increase sediment and nutrient loads, most noticeably in reservoirs with the highest VIs, reflecting the most degraded catchments. Additionally, we hypothesised that because inflows would likely increase horizontal advection and reduce water residence times (essentially flushing the reservoirs) but also increase light attenuation, phytoplankton measures such as biomass and cell density would be lower than under more typical (lower) inflow conditions. Thus, water quality measures such as nutrients and sediments would reflect, in large part, catchment effects, while phytoplankton measures would reflect internal processes.

\section{Study sites}

The 7 reservoirs examined in this study (Baroon Pocket, Cooloolabin, Hinze, Leslie Harrison, North Pine, Somerset, and Wivenhoe) are drinking water reservoirs managed by Seqwater in southeast Queensland, Australia (Fig. 1, Table 1). They are mesotrophic to eutrophic and are warm monomictic, undergoing thermal stratification during the austral summer. Natural bushland and pastoral activities (mainly cattle grazing) are the dominant land cover and land uses in the catchments, with the catchment of Wivenhoe reservoir having by far the highest percentage of grazing land cover (67\%). Cooloolabin and Wivenhoe reservoirs are, respectively, the smallest and largest reservoirs in terms of water storage capacities, surface areas, and catchment areas. Leslie Harrison is the shallowest and Hinze the deepest. 


\section{Methods}

\section{Study design: sampling periods}

This study combines data we collected from the 7 reservoirs in February 2011 (InflowSummer 2011) and June 2011 (Winter 2011) with data from 2 previous studies conducted in February 2005 (Summer 2005; Burford et al. 2007) and February 2009 (Summer 2009; Leigh et al. 2010a). One month prior to the Inflow-Summer 2011 period, major inflows to the reservoirs had occurred in association with widespread flooding across the entire study region resulting from extreme heavy rainfall during the 2010-2011 austral spring-summer (NCC BOM 2011, Leigh et al. 2014), whereas the previous sampling periods were associated with low to medium rainfall and inflow conditions (Burford et al. 2007, Leigh et al. 2010a).

\section{Field sampling and laboratory analyses}

We collected samples from each reservoir during the Inflow-Summer 2011 and Winter 2011 periods at dam wall, mid-reservoir, and upstream locations (Table 1) following methods outlined in Leigh et al. (2010a). We measured water temperature $\left({ }^{\circ} \mathrm{C}\right)$, electrical conductivity (specific conductance at $25^{\circ} \mathrm{C} ; \mu \mathrm{S} \mathrm{cm}{ }^{-1}$ ), $\mathrm{pH}$, and dissolved oxygen concentration (DO, mg $\mathrm{L}^{-1}$ ) once at the surface and once at the bottom of the water column at each location using a multiparameter sonde (YSI 6920, Yellow Springs, OH, USA). Secchi depth (m) was measured once at each location before using a modified PVC pipe-sampler to collect duplicate $3 \mathrm{~m}$ depth-integrated samples of surface water to later determine via laboratory analyses mean concentrations of chlorophyll $a$ (Chl- $\left.a, \mu g \mathrm{~L}^{-1}\right)$, total suspended solids (TSS, $\mathrm{mg} \mathrm{L}^{-1}$ ), total nitrogen and phosphorus ( $\mathrm{TN}$ and $\mathrm{TP}, \mathrm{mg} \mathrm{L}^{-1}$ ), dissolved inorganic nitrogen and phosphorus (nitrate plus nitrite $\left[\mathrm{NO}_{3}+\mathrm{NO}_{2}\right]$, ammonium $\left[\mathrm{NH}_{4}\right]$, and filterable reactive phosphorus [FRP]; mg L ${ }^{-1}$ ) for each location, following standard analytical methods with nutrient concentrations determined colorimetrically and Chl- $a$ measured 
spectrophotometrically from acetone-extracted samples (APHA 2005). In the field, all samples to be analyzed for dissolved nutrient concentrations were filtered through $0.45 \mu \mathrm{m}$ pore-size membrane filters (Merck Millipore, Billercia, MA, USA) and a subsample of one of each of the surface-water duplicates was fixed with Lugol's iodine solution ( $0.6 \%$ final concentration) to later identify and count phytoplankton taxa (cells $\mathrm{mL}^{-1}$ ) to species level, where possible, under 400× phase-contrast microscopy using a Sedgewick Rafter cell (Lund et al. 1958). Enumeration for each taxon ceased when 26 units (with a minimum of 3 squares) or 50 squares on the cell were counted, whichever was reached first (Hötzel and Croome 1999). Phytoplankton biovolumes $\left(\mathrm{mm}^{3} \mathrm{~L}^{-1}\right)$ were determined following standard methods (Hillebrand et al. 1999, Hötzel and Croome 1999). Duplicate bottom water samples were also collected from each location with a Van Dorn sampler (Wilco, Yulee, FL, USA) and analyzed for all of the above measures except for those associated with phytoplankton. All laboratory analyses were conducted at the National Association of Testing Authorities (NATA, www.nata.asn.au) accredited ALS Environmental laboratories (Stafford, Queensland, Australia).

In Summer 2005, 5 of the 7 reservoirs (Hinze, Leslie Harrison, North Pine, Somerset, and Wivenhoe) were sampled at the dam wall and upstream locations only (Burford et al. 2007; Table 1), and in Summer 2009, all 7 reservoirs were sampled at the same dam wall, mid-reservoir, and upstream locations that we sampled in 2011 (Leigh et al. 2010a; Table 1). Field sampling and laboratory analysis of samples collected in 2005 and 2009 followed methods outlined above (see also Burford et al. 2007, Leigh et al. 2010a), although TSS concentrations were not determined in 2005.

We report total phytoplankton and total cyanobacteria as biovolumes $\left(\mathrm{mm}^{3} \mathrm{~L}^{-1}\right)$, but also as densities (cells $\mathrm{mL}^{-1}$ ) because previous research on these reservoirs has shown a high correlation between densities and both catchment land use and the VI (Burford et al. 2007, 
Leigh et al. 2010 a, 2010b); prior to the present study, relationships between the VI and biovolumes were not invesitgated. We also calculated the proportion of total phytoplankton that consisted of cyanobacteria. It is difficult to accurately determine the contribution of phytoplankton to TSS; however, following rainfall, TSS is typically dominated by soil particles from the region's highly eroded catchments (Saxton et al. 2012).

\section{Data analysis}

The VI is a comparative index of summer vulnerability to poor water quality and cyanobacteria blooms. It is unitless, ranges from 0 (least vulnerable) to 1 (most vulnerable), and is calculated using 5 variables previously identified as predictive indicators of long-term water quality in subtropical reservoirs (Leigh et al. 2010a, 2010b; Table 1):

$$
\begin{aligned}
& \text { VI = (proportion cattle-grazing land cover + shoreline perimeter length to } \\
& \text { surface area ratio at full supply capacity + volume at full supply capacity + } \\
& \text { volume at full supply capacity to catchment area ratio + age since dam } \\
& \text { completion) } / 5
\end{aligned}
$$

Prior to calculation of the VI, the component variables are log transformed when necessary to reduce skew, then all 5 variables are standardised so that their highest value $=1$ and their lowest value $=0$.

We calculated the VI using the ages of reservoirs in 2005, 2009, and 2011 to correspond with the Summer 2005, Summer 2009, and the Inflow-Summer 2011 and Winter 2011 sampling periods, respectively. For each sampling period and reservoir, we then used regression analysis (DISTLM routine, PRIMER v6 plus PERMANOVA+ statistical package; Anderson et al. 2008) to determine the amount of variation that the VI could explain in 
selected groups of response variables based on measures taken from surface waters (groups 1-5) or surface and bottom waters (groups 6-8): (1) total phytoplankton, (2) total cyanobacteria, (3) proportion cyanobacteria, (4) Chl-a, (5) Secchi depth, (6) TSS, (7) TN and TP, and (8) $\mathrm{NO}_{3}+\mathrm{NO}_{2}, \mathrm{NH}_{4}$, and FRP. We refer to response variable groups $1-4$ as phytoplankton measures and 5-8 as other water quality measures. Data were transformed when necessary to meet assumptions of the analysis; the log transformation was applied to density and biovolume data, Chl- $a$, TSS, TN, and TP; and the arcsine squareroot transformation was applied to cyanobacteria proportions.

To investigate relationships among phytoplankton composition, sampling periods and the VI, we performed a principal coordinates analysis (PCO routine, PRIMER v6 plus PERMANOVA+ statistical package; Anderson et al. 2008) on centroids among Bray-Curtis similarities of log-transformed biovolume data from each reservoir and sampling period combination, overlayed with vectors of the Spearman-rank correlations between the PCO axes and the VI, proportions of different phytoplankton groups (diatoms, cyanobacteria, potentially toxic species), and the other phytoplankton and water quality measures listed above. Potentially toxic species (PTS) included Anabaena circinalis, Anabaena bergii, Aphanizomenon ovalisporum, and Microcystis aeruginosa but primarily consisted of Cylindrospermopsis raciborskii (simple linear regression between the biovolumes of PTS and C. raciborskii across all samples: $\left.\mathrm{R}^{2}=0.99\right)$. Sample biovolumes of PTS were also strongly reflective of those of all cyanobacteria $\left(\mathrm{R}^{2}=0.96\right)$.

\section{Results}

Heavy rainfall prior to the extreme events of Inflow-Summer 2011 was concentrated during October and December 2010 and January 2011 (NCC BOM 2011), well exceeding the regional 30 year rainfall means for these 3 months (Fig. 2; 50-200 mm, 100-200 mm and 
100-300 mm, respectively; Australian Bureau of Meteorology, http://www.bom.gov.au/climate/data/). Rainfall in the catchments of Wivenhoe and Cooloolabin, the 2 most distinct reservoirs in the study region in terms of their physical dimensions (Table 1), ranged from 220-281 mm in October 2010 to $~ 540-860 \mathrm{~mm}$ in January 2011 (Fig. 2). By contrast, rainfall in the months leading up to the Summer 2005 and Summer 2009 sampling periods was either below or similar to the 30 year means (Fig. 2). Unfortunately, estimates of inflow volumes and water residence times were unavailable for most reservoirs and sampling periods, in part because the extremity of the January 2011 event inactivated the flow-gauging stations; however, estimates for Somerset and Wivenhoe reservoirs indicate that $\sim 4$ times their volume was exchanged over the few weeks of the 2011 event period, whereas under typical conditions water residence times are likely to be on the order of several months to years (K. O’Brien, University of Queensland, 2013, unpubl. data; Table 2).

The comparative vulnerability of reservoirs to poor water quality and cyanobacteria blooms was stable among sampling periods; Wivenhoe had the highest VI and Cooloolabin the lowest, with Baroon Pocket having a mid-range value (Fig. 3). The VI, however, only explained a small amount of variation in phytoplankton measures during Inflow-Summer 2011 compared with that explained during Summer 2005 and Summer 2009 (Fig. 4). By contrast, the amount of variation in phytoplankton measures explained by the VI during Inflow-Summer 2011 was most similar to that explained during Winter 2011 (Fig. 4), which is considered the low-growth season (Burford and O’Donohue 2006). The amount of variation in TSS and dissolved nutrient concentrations explained by the VI during Inflow-Summer 2011 was higher than during the other summer periods, but similar to that explained during Winter 2011 (Fig. 4). For Secchi depth, the amount of variation explained by the VI during InflowSummer 2011 was similar to that explained during the other summer periods, while the 
variation explained in total nutrient concentrations did not follow patterns seen in the other variables (Fig. 4).

Water temperature, dissolved oxygen and $\mathrm{pH}$ within reservoirs were comparable among the summer sampling periods (Appendix S1); conductivity, however, was much lower during the Inflow-Summer 2011 than during Summer 2005 and Summer 2009, likely reflecting the high inflow volumes received by reservoirs during January 2011. TSS and nutrient concentrations in bottom waters were similar to or higher than in surface waters (Appendix S2); subsequent figures show surface water concentrations only. TSS and nutrient concentrations, particularly TP and FRP, generally increased with the VI, and among sampling periods were most often the highest during Inflow-Summer 2011 (Fig. 5). Densities and biovolumes of total phytoplankton and cyanobacteria also tended to increase with the VI (Fig. 6); however, phytoplankton measures, including total phytoplankton densities and cyanobacteria biovolumes and proportions, as well as Secchi depth, were generally lower during Inflow-Summer 2011 than other summers, particularly for the reservoirs with the highest VIs (Fig. 6).

Consistent patterns of increase or decrease in Secchi depth and TSS and nutrient concentrations were observed across the reservoirs with the lowest, intermediate, and highest VIs (Cooloolabin, Baroon Pocket and Wivenhoe, respectively) regardless of sampling period (Fig. 7). As the VI increased, TSS and nutrient concentrations (particularly TP and FRP) tended to increase, whereas Secchi depth decreased (Fig. 7). Patterns in concentrations of FRP, $\mathrm{NO}_{3}+\mathrm{NO}_{2}$ and $\mathrm{TN}$ (not shown) followed those of TP (Fig. 7). By contrast, while phytoplankton measures including total phytoplankton biovolumes and densities, cyanobacteria densities, and Chl- $a$ followed patterns of increase across the 3 reservoirs from lowest to highest VI during Summer 2009, Wivenhoe and Cooloolabin had similar values for these measures during Inflow-Summer 2011 (Fig. 7; Chl- $a$ and total phytoplankton densities 
not shown but followed patterns in total biovolumes and cyanobacteria densities, respectively; see also Fig. 6).

Phytoplankton composition of samples was strongly differentiated between sampling periods, with samples from Inflow-Summer 2011 and Winter 2011 grouping together and separately from the other summer periods in Bray-Curtis ordination space, primarily along PCO axis 1 (which explained 21.6\% of the total variation; Fig. 8). PCO axis 1 was strongly and positively correlated with the proportion of cyanobacteria, including potentially toxic species, in samples and negatively with the proportion of diatoms (Spearman correlation coefficients between 0.54 and 0.65 in absolute value; Fig. 8), indicating that the phytoplankton communities of reservoirs during Inflow-Summer 2011 and Winter 2011 had lower proportions of cyanobacteria and C. raciborskii but greater proportions of diatoms than during the other summers. PCO axis 2 explained a further $14.5 \%$ of the variation and differentiated the composition of samples of high VI-scoring reservoirs (e.g., Somerset, Wivenhoe, and North Pine) from low VI-scoring reservoirs (e.g., Cooloolabin). The VI was strongly and positively correlated with PCO axis $2($ Spearman correlation coefficient $=0.74)$, which was also correlated positively with nutrient concentrations (particularly TP), total phytoplankton biovolume, and the proportion of diatoms in samples, and negatively with Secchi depth (Spearman correlation coefficients between 0.57 and 0.74 in absolute value; Fig. 8).

\section{Discussion}

This study shows that, following record-breaking rainfall across the study region and subsequent extreme inflows to reservoirs, nutrient and suspended solids concentrations correlated strongly with the VI (Leigh et al. 2010a), an index developed and originally validated under low to average rainfall conditions. Phytoplankton measures, however, were 
less indicative of the VI during the extreme inflow period than under more typical summer conditions. In subtropical Australia, reservoirs receive massive inputs of sediment and nutrient from catchments during episodic, unpredictable, and high-magnitude inflows that occur following extreme summer rainfall (Burford et al. 2012, Leigh et al. 2013). Studies on fallout radionuclides in the study region have shown that channel erosion from gullies and banks in the catchments is the major source of sediment in downstream waters, including reservoirs (Wallbrink 2004, Olley et al. 2013). During heavy rainfall and associated inflows there is also net movement of labile dissolved and fine particulate $\mathrm{P}$ as well as $\mathrm{N}$ from catchment soils and channel sediments downstream into Wivenhoe (Kerr et al. 2011a, 2011b; Garzon-Garcia et al. 2014), the reservoir with the highest VI in the study region. Although research indicates that both $\mathrm{N}$ and $\mathrm{P}$ are required to stimulate phytoplankton blooms in the reservoirs (Muhid et al. 2013, Burford et al. 2014), the increase in light attenuation associated with suspended sediment inputs during summer inflows is likely an additional and important factor regulating bloom formation. Even during non-event summers, the euphotic depth in many of these reservoirs is typically shallower than the surface mixed layer, identifying light as a key limiting factor for phytoplankton growth (Burford et al. 2006, 2007, O’Brien et al. 2009). During extreme summer inflows, this factor is likely exacerbated, acting to reduce phytoplankton biomass and inhibiting cyanobacterial bloom formation.

For at least 2 of the reservoirs, Somerset and Wivenhoe, $\sim 4$ times the volume of each reservoir was flushed during the 2011 event (K. O’Brien, University of Queensland, 2013, unpubl. data). The resulting annual water retention times for these reservoirs was substantially lower $(0.2-0.3 \mathrm{yr})$ than in previous years when water residence times were typically 1 to 2 orders of magnitude higher (Table 2). This finding suggests that flushing effects of the extreme inflows likely contributed, in addition to light-limitation effects, to the 
reduced phytoplankton biomass and the diminished dominance by cyanobacteria measured in these reservoirs in 2011 relative to previous summers.

While our findings therefore substantiate those of Leigh et al. (2010a), who showed that subtropical reservoirs can be ranked in terms of their water quality and vulnerability to past and future summer blooms of cyanobacteria based on catchment and reservoir characteristics, we also show that extreme inflows play a role in driving water quality and phytoplankton responses in these systems. In degraded catchments where rainfall promotes erosion processes and the transport of nutrients downstream, summer conditions with more typical inflow volumes than those of summer 2010-2011 are likely associated with an immediate response (increase in phytoplankton density, biovolume and biomass), but when extreme inflows occur the response may be delayed. We propose that the delayed response is in part due to high suspended solids concentrations reducing light availability (e.g., Beaver et al. 2013) and in part due to the flushing of phytoplankton cells out of reservoirs during overflow (e.g., Harris and Baxter 1996, An and Park 2002, Vanni et al. 2006).

We therefore propose that the low phytoplankton densities and biovolumes measured immediately following the extremes inflows reflect a temporary phenomenon; for instance, Harris and Baxter (1996) found that reduced phytoplankton biomass occurred for only 3 months on average after individual storm events in a subtropical reservoir. We suggest that in our study systems, internal processes such as sediment remineralization of ammonium and phosphate, coupled with autumn overturn, will eventually make event-delivered nutrients (originally sourced from the catchment) available for phytoplankton growth and the development of cyanobacterial blooms in subsequent summers. This prediction is consistent with a study of blooms in a Korean reservoir (An and Park 2002) in which water residence times of $<8 \mathrm{~d}$, as a result of monsoonal inflows, had a negative effect on phytoplankton 
biomass despite an increase in phosphorus input loads. As water residence times increased, however, phytoplankton biomass increased.

The effect of reduced water residence time is particularly marked on cyanobacterial dominance (Elliott 2010). Research shows that high-VI reservoirs in our study region are dominated by cyanobacteria, particularly during the summer months (Burford and O’Donohue 2006, Burford et al. 2006, Leigh et al. 2010a). One of the dominant species is the toxic diazotroph C. raciborskii, the biovolumes of which we found reflective of the whole cyanobacterial community. This species gains a competitive advantage via flexible strategies in response to $\mathrm{N}$ and $\mathrm{P}$ fluctuations, the ability to regulate buoyancy, and adaptation to low light conditions (Burford et al. 2006, O’Brien et al. 2009). Many cyanobacteria grow slowly, however, in particular C. raciborskii, typically with a doubling time of about $5 \mathrm{~d}$ (Muhid et al. 2013, Burford et al. 2014). Under typical conditions in the study reservoirs where water residence times are $>1$ year (Table 2), slow growth rates do not prevent dominance. Under high inflow conditions when reservoirs are rapidly flushed, however, cyanobacteria are likely to be negatively impacted in terms of absolute numbers and biomass and in terms of relative dominance compared with other faster growing groups, including diatoms (e.g., Fig. 8). Such phenomena are not unique to our study systems but have been observed in lakes and reservoirs elsewhere, in the subtropics and beyond (e.g., Elliott 2010, O’Farrell et al. 2012).

In summary, this study found that the VI remained a robust measure of water quality even under extreme inflow conditions, driven by differential increases in TSS and nutrients across reservoirs, but not phytoplankton measures. The VI clearly reflects higher phytoplankton biomass in higher VI reservoirs during summers with below-average or medium inflows, however, indicating that phytoplankton measures are longer-term integrators of water quality. The VI is therefore a useful measure of both short- and long-term processes that drive water quality in impounded rivers. 


\section{Acknowledgements}

This work was funded by Queensland Bulk Water Supply Authority (Seqwater). We thank onsite managers and water quality monitoring staff at Seqwater, and Stephen Faggotter, Christina Laurikaunen, Tim Davis, and Carolyn Polson for assistance with field work in 2011; Priyanesh Muhid for discussions on laboratory procedures; and the authors of previous studies (Burford et al. 2007, Leigh et al. 2010a) for data access. We thank Seqwater for access to water quality data. Comments from 2 anonymous reviewers improved the manuscript.

\section{References}

[APHA] American Public Health Association. 2005. Standard methods for the examination of water and wastewater, $21^{\text {st }}$ ed. Washington (DC).

An K-G, Park SS. 2002. Indirect influence of the summer monsoon on chlorophyll-total phosphorus models in reservoirs: a case study. Ecol Modell. 152:191-203.

Anderson MJ, Gorley RN, Clarke RK. 2008. PERMANOVA+ for PRIMER: guide to software and statistical methods. Plymouth (UK): PRIMER-E.

Beaver JR, Casamatta DA, East TL, Havens KE, Rodusky AJ, James RT, Tausz CE, Buccier KM. 2013. Extreme weather events influence the phytoplankton community structure in a large lowland subtropical lake (Lake Okeechobee, Florida, USA). Hydrobiologia. 709:213-226.

Bosch N, Allan J. 2008. The influence of impoundments on nutrient budgets in two catchments of southeastern Michigan. Biogeochemistry. 87:325-338. 
Burford MA, Davis TW, Orr PT, Sinha R, Willis A, Neilan BA. 2014. Nutrient-related changes in the toxicity of field blooms of the cyanobacterium, Cylindrospermopsis raciborskii. FEMS Microbiol Ecol. 89:135-148.

Burford M, Green S, Cook A, Johnson S, Kerr J, O’Brien K. 2012. Sources and fate of nutrients in a subtropical reservoir. Aquat Sci. 74:179-190.

Burford MA, Johnson SA, Cook AJ, Packer TV, Taylor BM, Townsley ER. 2007.

Correlations between watershed and reservoir characteristics, and algal blooms in subtropical reservoirs. Water Res. 41:4105-4114.

Burford MA, McNeale KL, McKenzie-Smith FJ. 2006. The role of nitrogen in promoting the toxic cyanophyte Cylindrospermopsis raciborskii in a subtropical water reservoir. Freshwater Biol. 51:2143-2153.

Burford MA, O’Donohue MJ. 2006. A comparison of phytoplankton community assemblages in artificially and naturally mixed subtropical water reservoirs. Freshwater Biol. 51:973-982.

Carney E. 2009. Relative influence of lake age and watershed land use on trophic state and water quality of artificial lakes in Kansas. Lake Reserv Manage. 25:199-207.

Carpenter SR, Caraco NF, Correll DL, Howarth RW, Sharpley AN, Smith VH. 1998. Nonpoint pollution of surface waters with phosphorus and nitrogen. Ecol Appl. 8:559_ 568.

Davis JR, Koop K. 2006. Eutrophication in Australian rivers, reservoirs and estuaries - a southern hemisphere perspective on the science and its implications. Hydrobiologia. 559:23-76.

Elliott JA. 2010. The seasonal sensitivity of Cyanobacteria and other phytoplankton to changes in flushing rate and water temperature. Glob Change Biol. 16:864-876. 
Garzon-Garcia A, Olley JM, Bunn SE. 2014. Controls on carbon and nitrogen export in an eroding catchment of south-eastern Queensland, Australia. Hydrol Process. DOI: 10.1002/hyp.10192

Harris GP, Baxter G. 1996. Interannual variability in phytoplankton biomass and species composition in a subtropical reservoir. Freshwater Biol. 35:545-560.

Harrison J, Maranger R, Alexander R, Giblin A, Jacinthe P-A, Mayorga E, Seitzinger S, Sobota D, Wollheim W. 2009. The regional and global significance of nitrogen removal in lakes and reservoirs. Biogeochemistry. 93:143-157.

Hillebrand H, Dürselen C-D, Kirschtel D, Pollingher U, Zohary T. 1999. Biovolume calculation for pelagic and benthic microalgae. J Phycol. 35:403-424.

Hötzel G, Croome R. 1999. A phytoplankton methods manual for Australian waters. Canberra (Australia): Land and Water Resources Research and Development Corporation. Occasional paper series 22/99.

Jones JR, Knowlton MF, Obrecht DV, Cook EA. 2004. Importance of landscape variables and morphology on nutrients in Missouri reservoirs. Can J Fish Aquat Sci. 61:15031512.

Katsiapi M, Moustaka-Gouni M, Michaloudi E, Kormas K. 2011. Phytoplankton and water quality in a Mediterranean drinking-water reservoir (Marathonas Reservoir, Greece). Environ Monit Assess. 181:563-575.

Kerr JG, Burford MA, Olley JM, Bunn SE, Udy J. 2011a. Examining the link between terrestrial and aquatic phosphorus speciation in a subtropical catchment: the role of selective erosion and transport of fine sediments during storm events. Water Res. 45:3331-3340. 
Kerr JG, Burford M, Olley J, Udy J. 2011b. Phosphorus sorption in soils and sediments: implications for phosphate supply to a subtropical river in southeast Queensland, Australia. Biogeochemistry. 102:73-85.

Leigh C, Burford MA, Connolly RM, Olley JM, Saeck E, Sheldon F, Smart JCR, Bunn SE. 2013. Science to support management of receiving waters in an event-driven ecosystem: from land to river to sea. Water. 5:780-797.

Leigh C, Burford MA, Roberts DT, Udy JW. 2010a. Predicting the vulnerability of reservoirs to poor water quality and cyanobacterial blooms. Water Res. 44:4487-4496.

Leigh C, Burford MA, Roberts DT, Udy JW. 2010b. Cyanobacterial blooms: assessing reservoir vulnerability. Water. 37:71-75.

Leigh C, Bush A, Harrison ET, Ho SS, Luke L, Rolls RJ, Ledger ME. 2014. Ecological effects of extreme climatic events on riverine ecosystems: insights from Australia. Freshwater Biol. DOI: 10.1111/fwb.12522

Lund JWG, Kipling C, Cren ED. 1958. The inverted microscope method of estimating algal numbers and the statistical basis of estimations by counting. Hydrobiologia. 11:143170.

McGregor GB, Fabbro LD. 2000. Dominance of Cylindrospermopsis raciborskii (Nostocales, Cyanoprokaryota) in Queensland tropical and subtropical reservoirs: implications for monitoring and management. Lake Reserv Res Manage. 5:195-205.

Muhid P, Davis TW, Bunn SE, Burford MA. 2013. Effects of inorganic nutrients in recycled water on freshwater phytoplankton biomass and composition. Water Res. 47:384-394.

O’Brien KR, Burford MA, Brookes JD. 2009. Effects of light history on primary productivity in a phytoplankton community dominated by the toxic cyanobacterium Cylindrospermopsis raciborskii. Freshwater Biol. 54:272-282. 
O’Farrell I, Bordet F, Chaparro G. 2012. Bloom forming cyanobacterial complexes cooccurring in a subtropical large reservoir: validation of dominant eco-strategies. Hydrobiologia. 698:175-190.

Olley J, Burton J, Smolders K, Pantus F, Pietsch T. 2013. The application of fallout radionuclides to determine the dominant erosion process in water supply catchments of subtropical South-east Queensland, Australia. Hydrol Process. 26:885-895.

O’Neil JM, Davis TW, Burford MA, Gobler CJ. 2012. The rise of harmful cyanobacteria blooms: role of eutrophication and climate change in freshwater, estuarine and marine ecosystems. Harmful Algae. 14:313-334.

[NCC BOM] National Climate Centre Bureau of Meteorology. 2011. Frequent heavy rain events in late 2010/early 2011 lead to widespread flooding across eastern Australia. Special climate statement 24. Melbourne (Australia): Bureau of Meteorology. Available from: http://www.bom.gov.au/climate/current/special-statements.shtml

Nielsen A, Trolle D, Søndergaard M, Lauridsen TL, Bjerring R, Olesen JE, Jeppesen, E. 2012. Watershed land use effects on lake water quality in Denmark. Ecol. Appl. 22:1187-1200.

Romo S, Soria J, Fernández F, Ouahid Y, Barón-Solá Á. 2013. Water residence time and the dynamics of toxic cyanobacteria. Freshwater Biol. 58:513-522.

Saxton NE, Olley JM, Smith S, Ward DP, Rose CW. 2012. Gully erosion in sub-tropical south-east Queensland, Australia. Geomorphology. 173:80-87.

Schindler DW. 2006. Recent advances in the understanding and management of eutrophication. Limnol Oceanogr. 51:356-363.

Smith V. 2003. Eutrophication of freshwater and coastal marine ecosystems a global problem. Environ Sci Pollut Res. 10:126-139. 
Syvitski JPM, Vorosmarty CJ, Kettner AJ, Green P. 2005. Impact of humans on the flux of terrestrial sediment to the global coastal ocean. Science. 308:376-380

Vanni MJ, Andrews JS, Renwick WH, Gonzalez MJ, Noble SJ. 2006. Nutrient and light limitation of reservoir phytoplankton in relation to storm-mediated pulses in stream discharge. Arch Hydrobiol. 167:421-445.

Wallbrink PJ. 2004. Quantifying the erosion processes and land-uses which dominate fine sediment supply to Moreton Bay, Southeast Queensland, Australia. J Environ Radioactiv. 76:67-80.

Wetzel RG. 2001. Limnology: lake and river ecosystems, $3^{\text {rd }}$ ed. San Diego (CA): Academic Press.

Xu H, Paerl HW, Qin B, Zhu G, Gao G. 2010. Nitrogen and phosphorus inputs control phytoplankton growth in eutrophic Lake Taihu, China. Limnol Oceanogr 55:420-432. Zohary T, Ostrovsky I. 2011. Do water level fluctuations matter? Inland Waters 1:47-59.

Fig. 1. Study region showing 7 reservoirs (closed triangles) in subtropical southeast Queensland, Australia. Lines indicate boundaries of the river basins in which the reservoirs are located.

Fig. 2. Monthly rainfall (mm) recorded at rainfall gauging stations near (A) Wivenhoe and (B) Cooloolabin dam walls in the 4 months leading up to the Summer 2005, Summer 2009 and Inflow-Summer 2011 sampling periods, compared with the average monthly rainfall across the study region. Source: Australian Bureau of Meteorology, http://www.bom.gov.au/climate/data/, cited 18 April 2013. 
Fig. 3. Vulnerability Index in 2005, 2009, and 2011 for 7 subtropical reservoirs sampled in 2005 (except Cooloolabin and Baroon Pocket), 2009, and 2011.

Fig. 4. The Vulnerability Index (VI) explains a smaller, similar, or greater amount of variation in the phytoplankton and water quality response variables during Inflow-Summer 2011 than other sampling periods, depending on the type of response variable (see Results for detail). Phytoplankton response variables include PhytoD and PhytoBV (total phytoplankton in cells $\mathrm{mL}^{-1}$ and $\mathrm{mm}^{3} \mathrm{~L}^{-1}$ ), CyanoD and CyanoBV (cyanobacteria in cells $\mathrm{mL}^{-1}$ and $\mathrm{mm}^{3}$ $\mathrm{L}^{-1}$ ), CyanoD\% (proportion cyanobacteria based on densities, \%), chlorophyll $a$ (Chl-a) concentration $\left(\mu \mathrm{g} \mathrm{L}^{-1}\right)$, and groups of nutrient-concentration response variables include total nitrogen and total phosphorus in surface and bottom waters (TNP, $\mathrm{mg} \mathrm{L}^{-1}$ ), and dissolved nitrogen and dissolved phosphorus in surface and bottom waters (DNP, $\mathrm{mg} \mathrm{L}^{-1}$ ).

Fig. 5. Total suspended solids (TSS) and nutrient concentrations of reservoirs (means \pm 1 standard deviation) during different sampling periods. $\mathrm{C}=$ Cooloolabin; $\mathrm{B}=$ Baroon Pocket; $\mathrm{H}$ = Hinze; L = Leslie Harrison; $\mathrm{N}$ = North Pine; $\mathrm{S}$ = Somerset; and $\mathrm{W}=$ Wivenhoe reservoir.

Fig. 6. Total phytoplankton densities and biovolumes, cyanobacteria biovolumes and proportions (based on densities), chlorophyll $a$ (Chl-a) concentration, and Secchi depth of reservoirs (means \pm 1 standard deviation) during different sampling periods. Note that the high Chl- $a$ concentration and total phytoplankton biovolume in Hinze reservoir in InflowSummer 2011 is an exceptional case due to one upstream site with readings of $70 \mathrm{ug} \mathrm{L}^{-1}$ and $47 \mathrm{~mm}^{3} \mathrm{~L}^{-1}$, respectively. $\mathrm{C}=$ Cooloolabin; $\mathrm{B}=$ Baroon Pocket; $\mathrm{H}=$ Hinze; $\mathrm{L}=$ Leslie Harrison; $\mathrm{N}=$ North Pine; $\mathrm{S}$ = Somerset; and $\mathrm{W}=$ Wivenhoe reservoir. 
Fig. 7. Patterns in cyanobacteria density, total phytoplankton biovolume, Secchi depth, total suspended solids (TSS), and total phosphorus (TP) across the VI gradient of reservoirs in Summer 2009, Inflow-Summer 2011, and Winter 2011. Cooloolabin (C) reservoir has the lowest VI, Wivenhoe (W) the highest, with Baroon Pocket (B) in between. No data are shown for Summer 2005 because C and B were not sampled in that period.

Fig. 8. Principal coordinates analysis of the phytoplankton communities of reservoirs during four sampling periods (Summer 2005, Summer 2009, Inflow-Summer 2011 and Winter 2011). The right panel shows vector overlays based on Spearman rank correlations between the axes and the VI, nutrient concentrations, and phytoplankton measures. Only vectors with correlation $>0.35$ in absolute value are displayed. The circle has a radius of 1.0. $\mathrm{C}=$ Cooloolabin; $\mathrm{B}$ = Baroon Pocket; $\mathrm{H}$ = Hinze; $\mathrm{L}$ = Leslie Harrison; $\mathrm{N}=$ North Pine; $\mathrm{S}=$ Somerset; and $\mathrm{W}=$ Wivenhoe reservoir. PhytoBV $=$ total phytoplankton in $\mathrm{mm}^{3} \mathrm{~L}^{-1}$; \%CyanoBV = proportion cyanobacteria based on biovolumes; \%DiatomsBV = proportion diatoms based on biovolumes; and \%PTSbv = proportion potentially toxic species based on biovolumes. See text for abbreviations of other measures (the subscript ' $s$ ' signifies surface water samples). 
1 Table 1. Characteristics of 7 reservoirs and their catchments in subtropical Queensland, Australia during the study period (2005-2011). Note:

2 some values vary slightly from those given in Leigh et al. (2010a) due to improved accuracy of estimates by reservoir managers.

\begin{tabular}{|c|c|c|c|c|c|c|c|c|c|}
\hline Reservoir & Locations sampled $^{\text {a }}$ & $\begin{array}{l}\text { Construction } \\
\text { competed }^{\mathrm{b}}\end{array}$ & $\begin{array}{l}\text { Volume at full } \\
\text { supply capacity } \\
\left(10^{6} \mathrm{~m}^{3}\right)\end{array}$ & $\begin{array}{l}\text { Shore length } \\
(\mathrm{km})\end{array}$ & $\begin{array}{l}\text { Surface area } \\
\left(\mathrm{km}^{2}\right)\end{array}$ & $\begin{array}{l}\text { Mean } \\
\text { depth (m) }\end{array}$ & $\begin{array}{l}\text { Catchment area } \\
\left(\mathrm{km}^{2}\right)\end{array}$ & $\begin{array}{l}\text { Pastoral land } \\
\text { cover in } \\
\text { catchment (\% } \\
\text { cattle grazing) }\end{array}$ & $\mathrm{VI}^{\mathrm{c}}$ \\
\hline Cooloolabin (C) & $\mathrm{D}, \mathrm{M}, \mathrm{U}$ & 1979 & 13.8 & 12.8 & 2.2 & 9.9 & 8.10 & 0 & 0.19 \\
\hline Hinze $(\mathrm{H})$ & $\mathrm{D}, \mathrm{M}, \mathrm{U}$ & 1989 & 163 & 67.4 & 9.5 & 17.5 & 207 & 12 & 0.25 \\
\hline Baroon Pocket (B) & $\mathrm{D}, \mathrm{M}, \mathrm{U}$ & 1989 & 61.0 & 25.5 & 3.8 & 15.7 & 67.0 & 50 & 0.36 \\
\hline Leslie Harrison (L) & $\mathrm{D}, \mathrm{M}, \mathrm{U}$ & 1968 & 24.9 & 34.5 & 4.8 & 5.9 & 87.0 & 13 & 0.41 \\
\hline North Pine (N) & $\mathrm{D}, \mathrm{M}, \mathrm{U}$ & 1976 & 214 & 167 & 20.7 & 10.1 & 348 & 30 & 0.43 \\
\hline Somerset (S) & $\mathrm{D}, \mathrm{M}, \mathrm{U}$ & 1959 & 380 & 237 & 42.1 & 9.3 & 1340 & 32 & 0.79 \\
\hline Wivenhoe (W) & $\mathrm{D}, \mathrm{M}, \mathrm{U}$ & 1984 & 1165 & 462 & 107 & 10.5 & 7020 & 67 & 0.85 \\
\hline
\end{tabular}

$3 \quad{ }^{\mathrm{a}} \mathrm{D}$ = dam wall; $\mathrm{M}$ = mid-reservoir; $\mathrm{U}=$ upstream. One D, M, and U location was sampled in each reservoir during the 2009 and 2011 sampling periods, except at Hinze,

4 Leslie Harrison, and North Pine reservoirs in which two U locations were sampled (one in each of the major inflow arms of these reservoirs; all other reservoirs have one

5 major inflow arm only). In 2005, one D and one U location was sampled in each reservoir (no M locations were sampled). See also Burford et al. (2007) and Leigh et al.

6 (2010a).

$7 \quad$ b Dam wall height at Hinze reservoir was raised and completed by end 2011, increasing the full supply capacity to $310.7 \times 10^{6} \mathrm{~m}^{3}$. The original dam wall at Leslie Harrison

8 reservoir was completed in 1968 but raised in 1984; data in following columns are associated with the 1984 dam height.

$9 \quad{ }^{\mathrm{c}}$ Vulnerability Index (VI; Leigh et al. 2010a), a comparative index of vulnerability to poor water quality and summer blooms of cyanobacteria, calculated for the 7 reservoirs

10 based on their age ( in years) in 2011 (see Methods for detail). 
12 Table 2. Annual water residence times (WRT) estimated for Somerset and Wivenhoe

13 reservoirs $^{\mathrm{a}}$.

\begin{tabular}{|c|c|c|c|c|}
\hline $\begin{array}{l}\text { Water year } \\
\text { start (1 Jul) }\end{array}$ & $\begin{array}{l}\text { Water year } \\
\text { end ( } 30 \text { Jun) }\end{array}$ & $\begin{array}{l}\text { Somerset } \\
\text { WRT (y) }\end{array}$ & $\begin{array}{l}\text { Wivenhoe } \\
\text { WRT (y) }\end{array}$ & Relevant sampling period(s) \\
\hline 1997 & 1998 & 1.71 & 4.78 & - \\
\hline 1998 & 1999 & 0.42 & 0.80 & - \\
\hline 1999 & 2000 & 1.20 & 2.63 & - \\
\hline 2000 & 2001 & 1.48 & 2.23 & - \\
\hline 2001 & 2002 & 3.33 & 5.26 & - \\
\hline 2002 & 2003 & 1.36 & 6.67 & - \\
\hline 2003 & 2004 & 1.41 & 3.48 & - \\
\hline 2004 & 2005 & 3.36 & 11.15 & Summer 2005 \\
\hline 2005 & 2006 & 2.45 & 12.87 & - \\
\hline 2006 & 2007 & 3.25 & 24.54 & - \\
\hline 2007 & 2008 & 0.78 & 5.11 & - \\
\hline 2008 & 2009 & 0.71 & 2.00 & Summer 2009 \\
\hline 2009 & 2010 & 0.79 & 1.90 & - \\
\hline 2010 & 2011 & 0.24 & 0.28 & Inflow-Summer 2011; Winter 2011 \\
\hline 2004 & 2010 & 1.89 & 9.60 & 6-y mean $(2004-2010)^{b}$ \\
\hline 1997 & 2011 & 1.61 & 5.98 & Grand mean (1997-2011) \\
\hline
\end{tabular}

$14{ }^{a}$ Unpubl. data (K. O’Brien, University of Queensland, 2013).

$15 \quad{ }^{\mathrm{b}}$ Average annual WRT across the 6-y period prior to Inflow-Summer 2011 that encompasses the previous 2 16 sampling periods. 


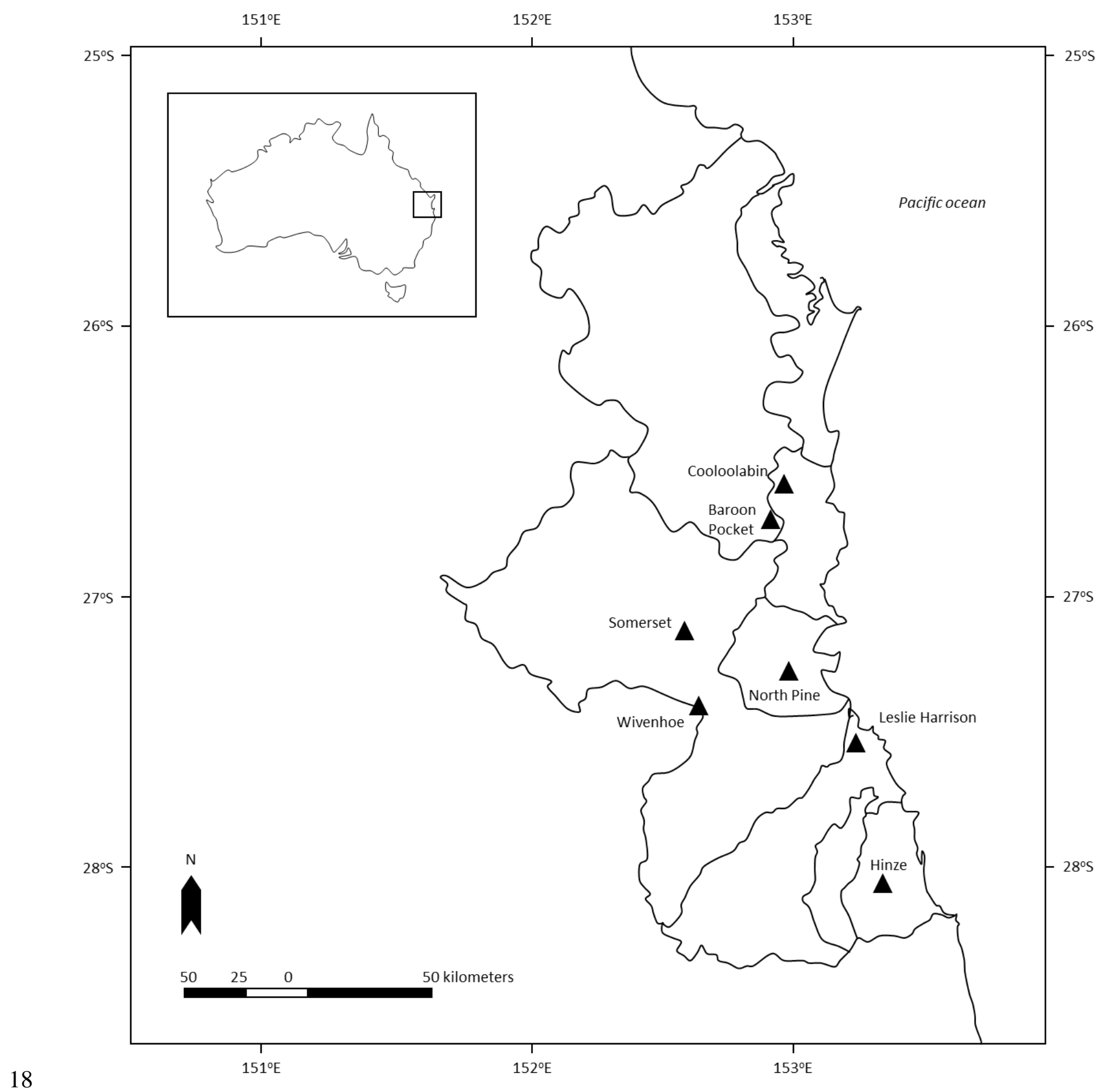

$19 \quad$ Fig. 1. 

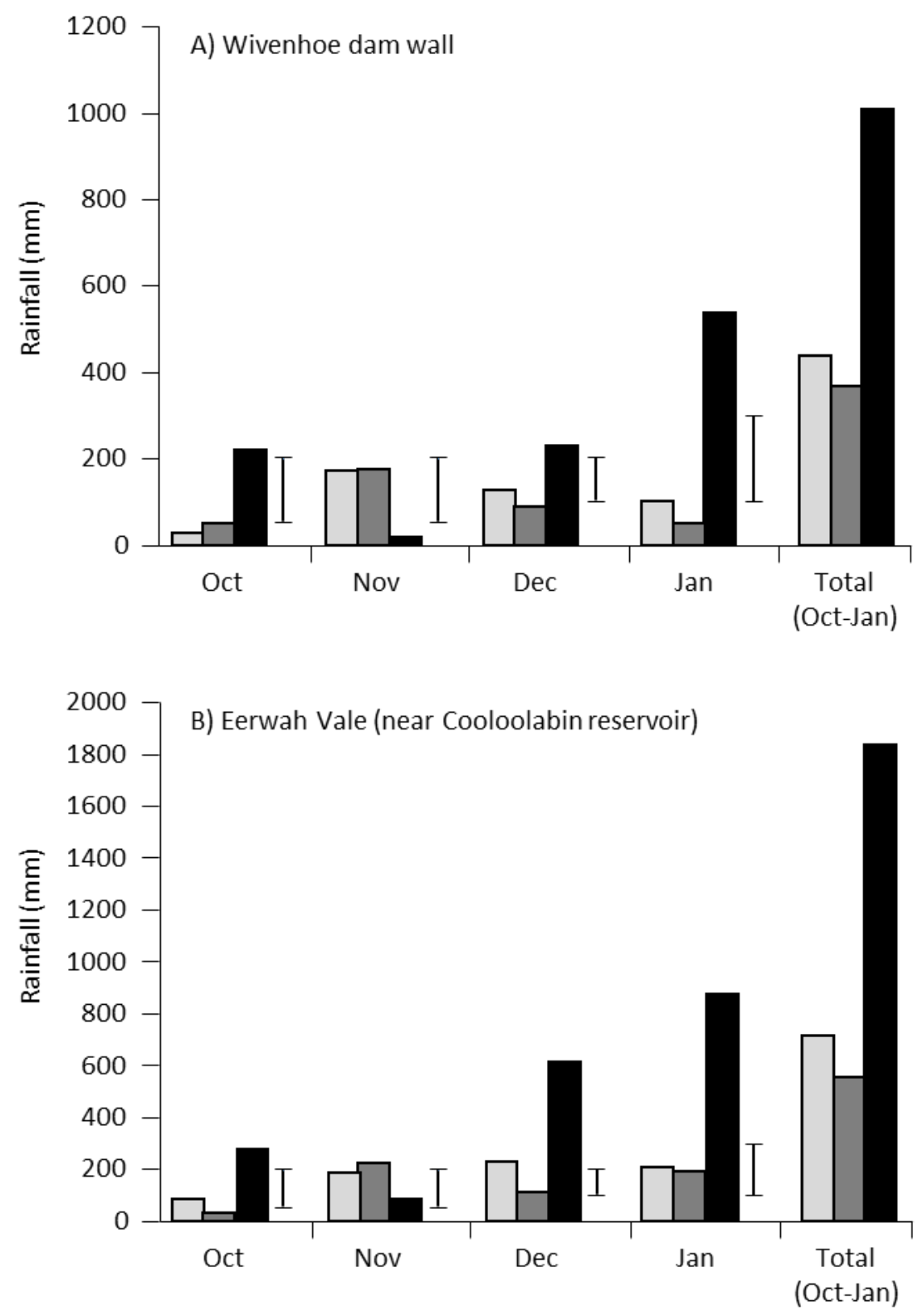

22

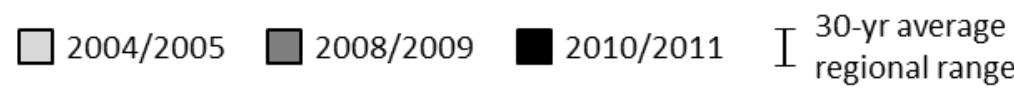

$23 \quad$ Fig. 2. 


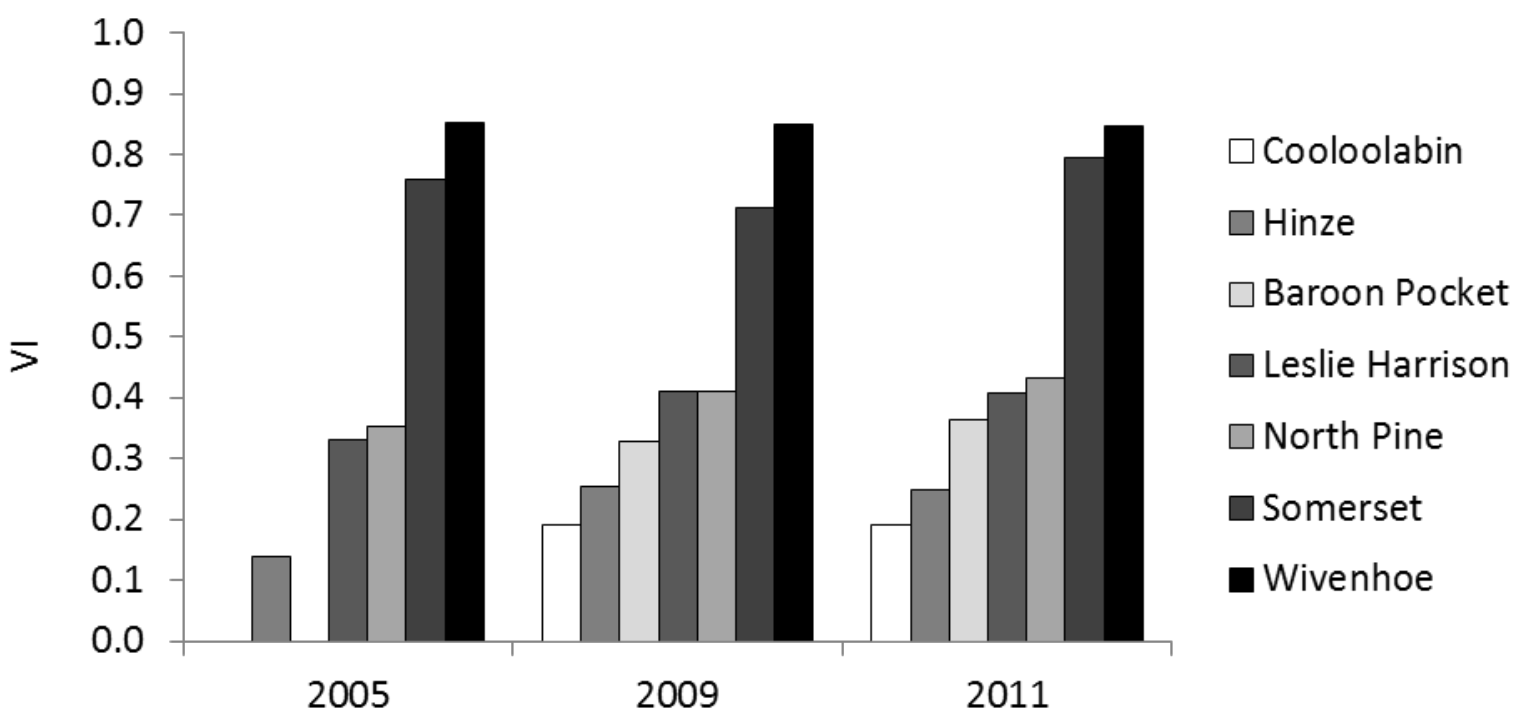

25

Fig. 3.

27 


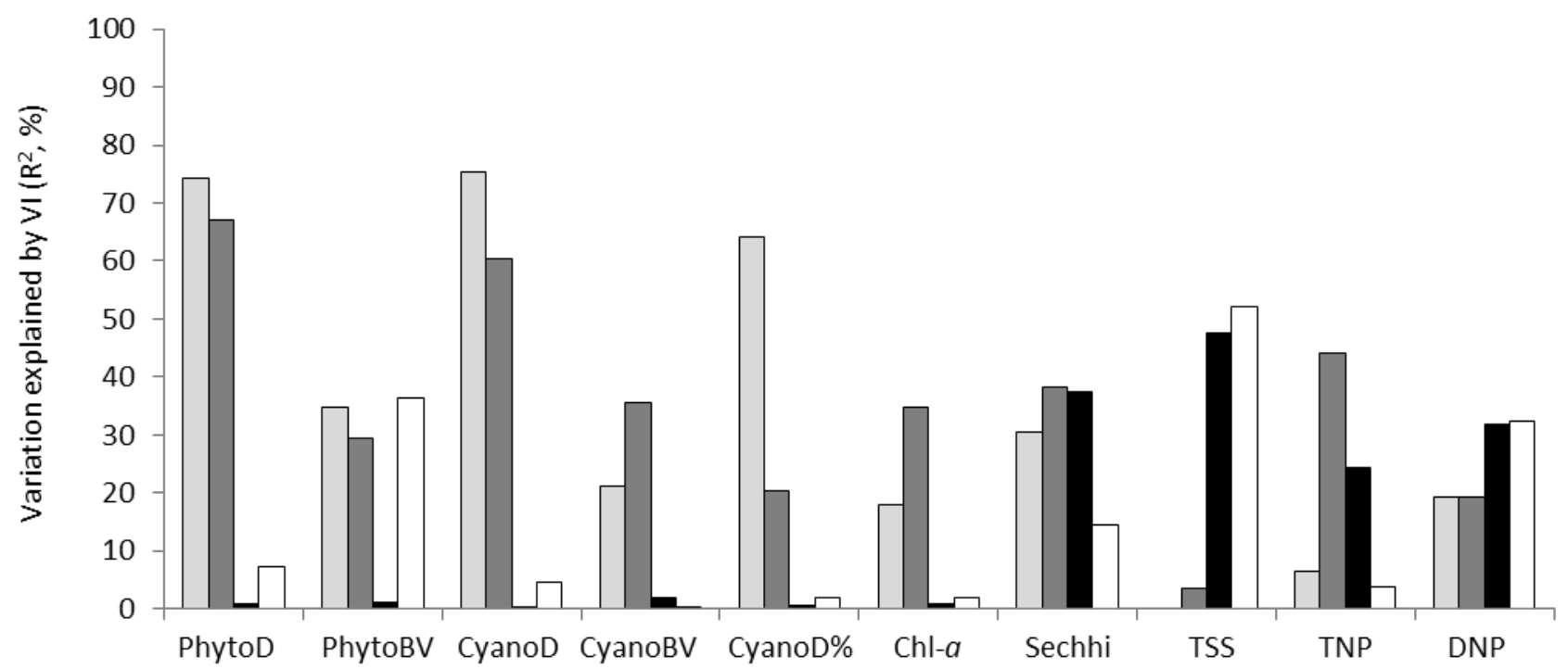

$30 \quad$ Fig. 4.

31 

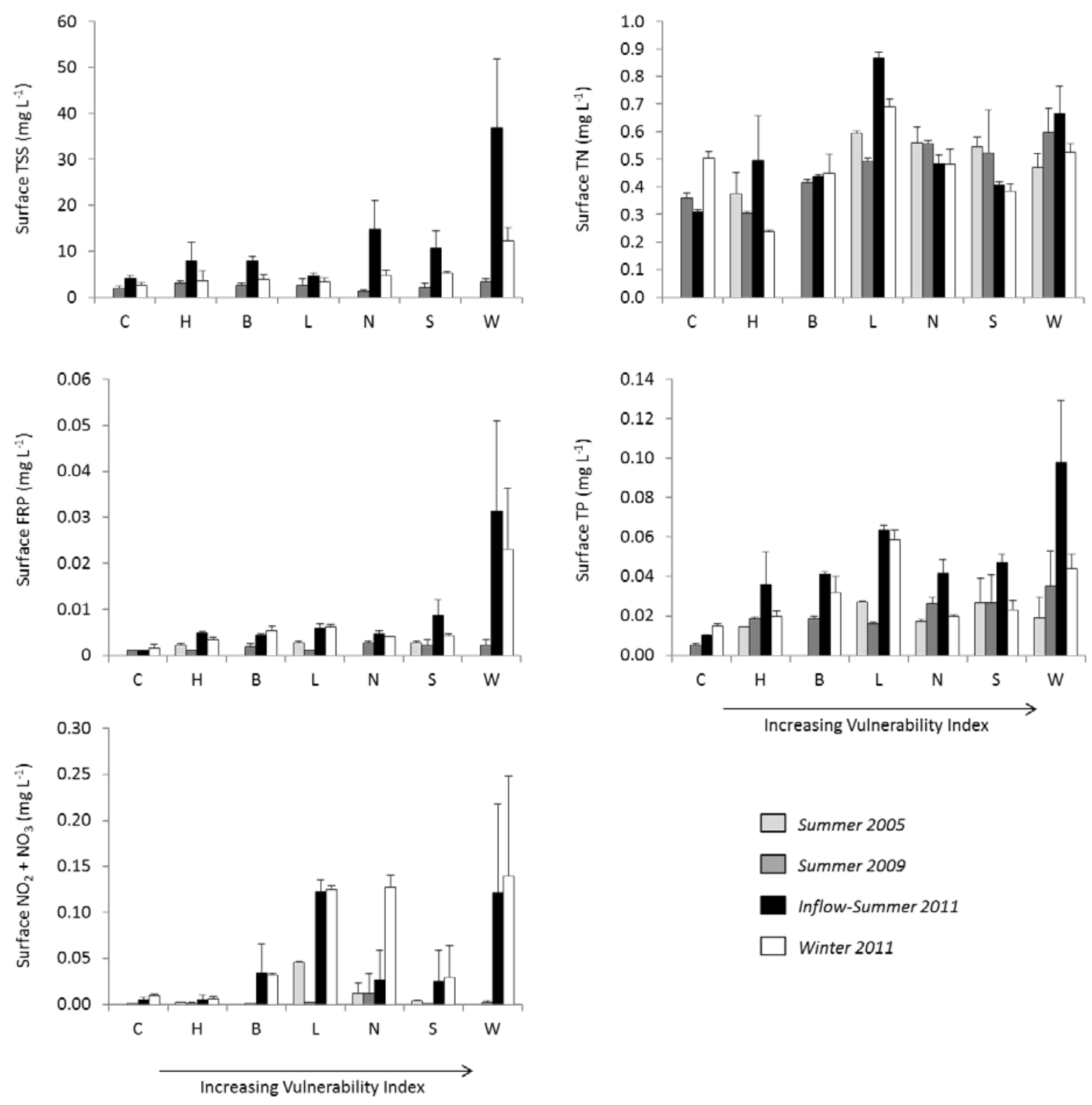

Increasing Vulnerability Index

Fig. 5. 

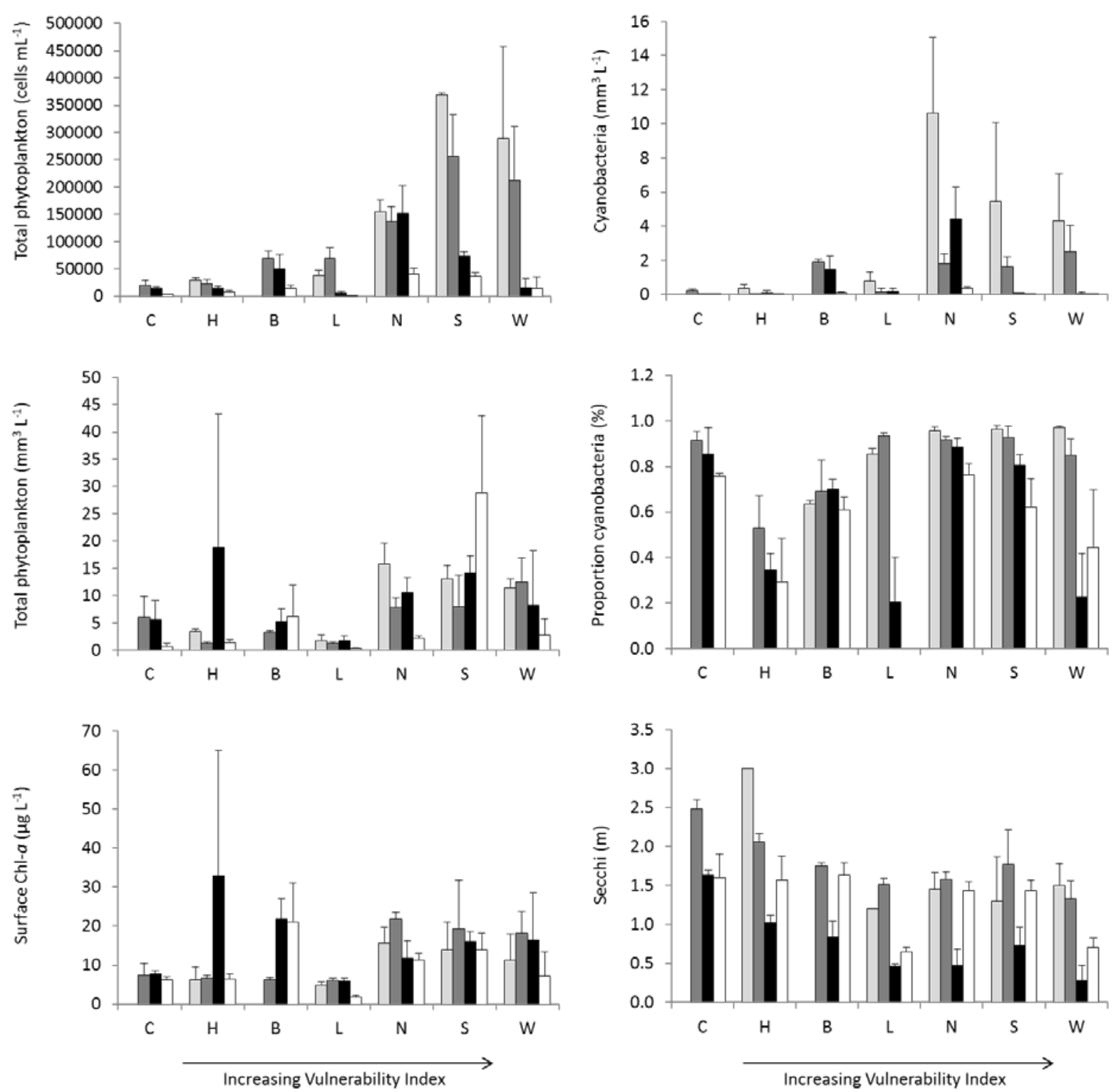

Fig. 6. 

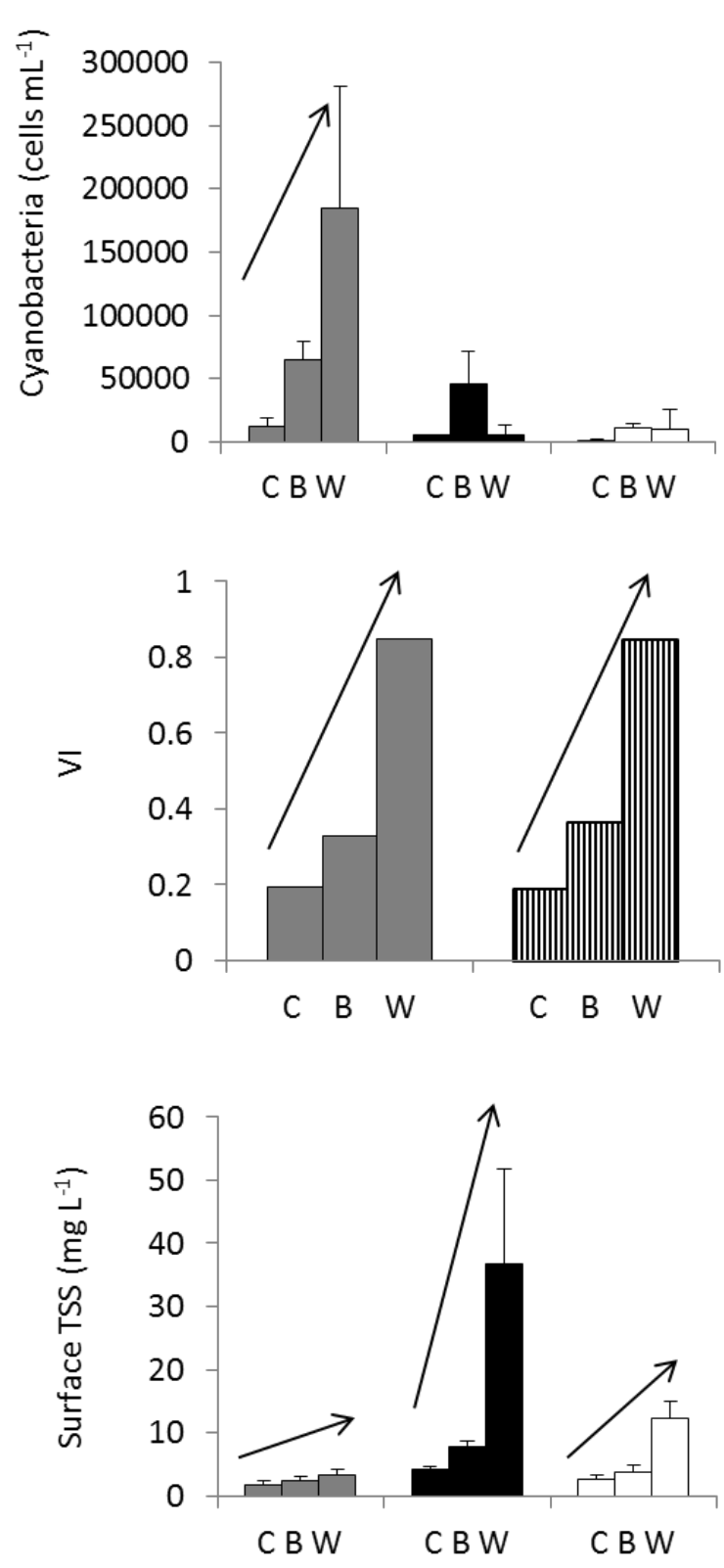
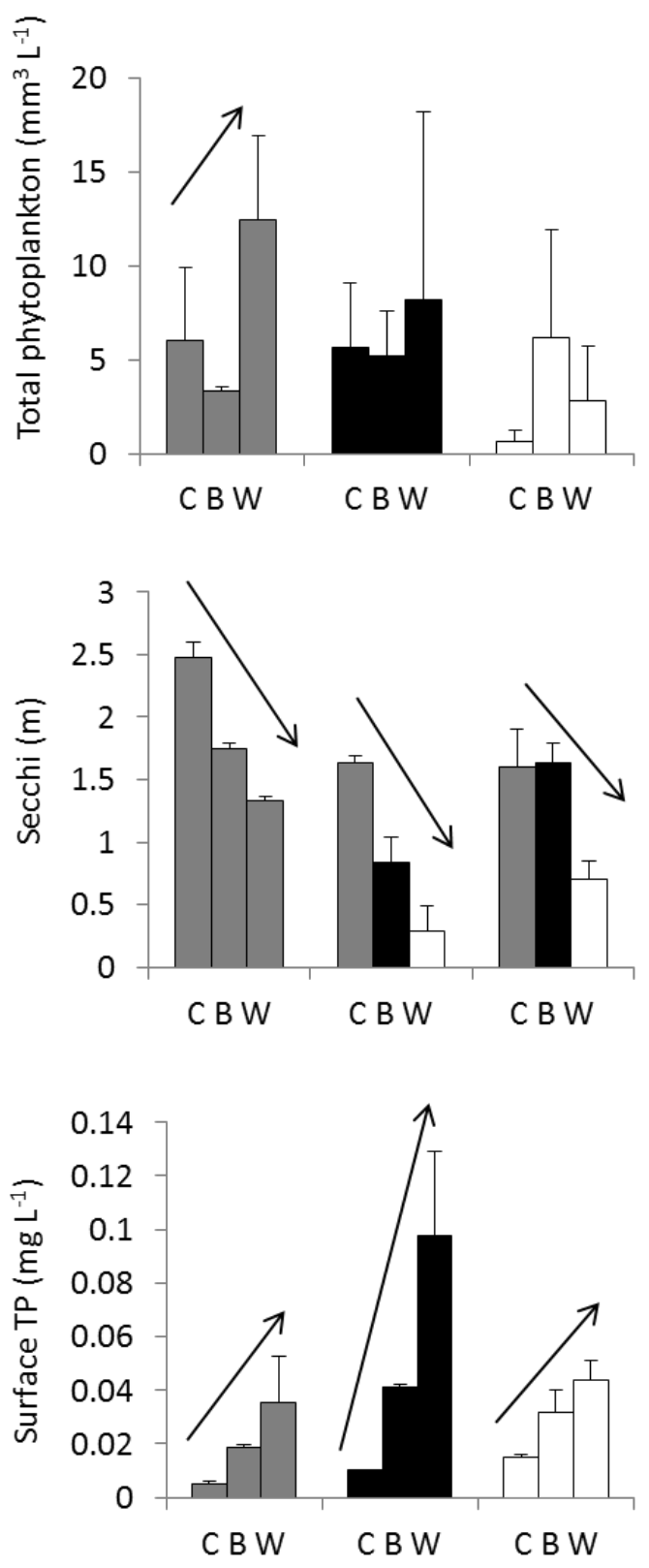

38

Fig. 7. 

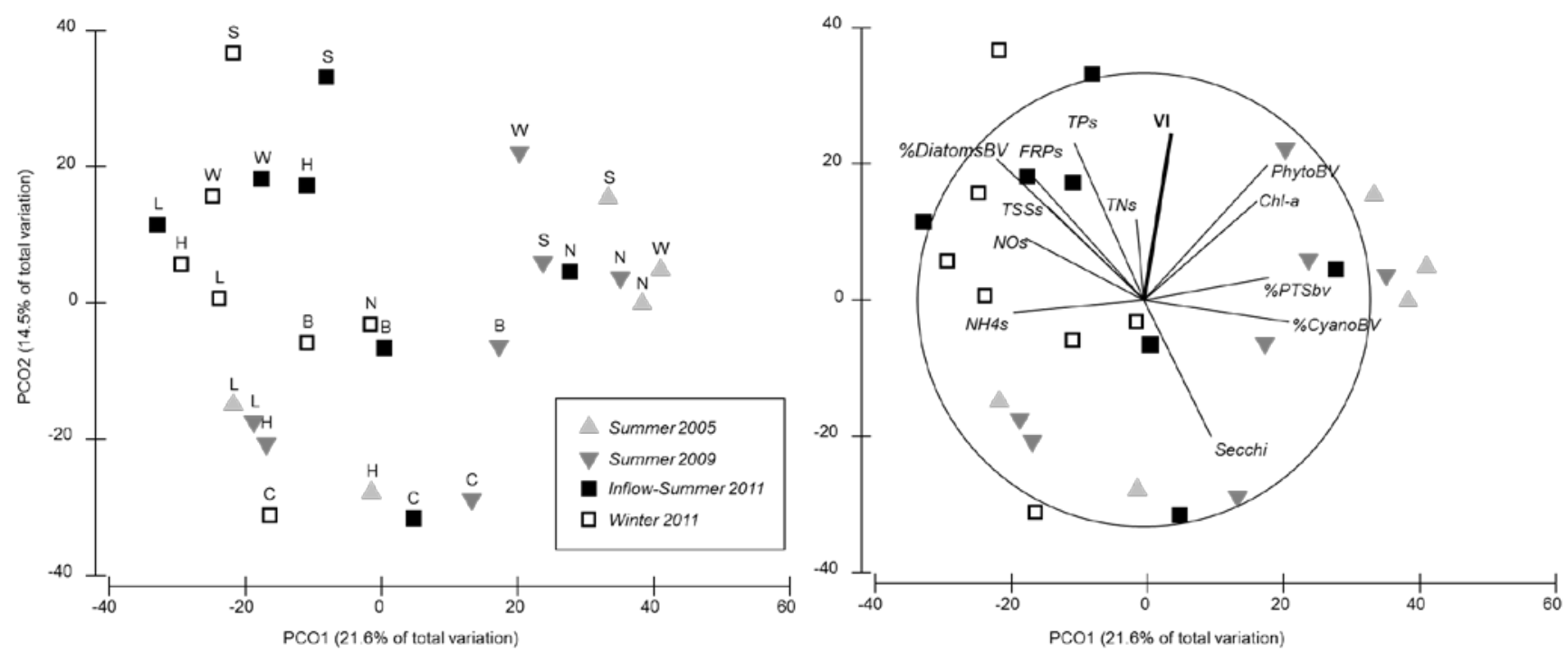

$42 \quad$ Fig. 8. 
Appendix S1. Mean surface and bottom water quality of reservoirs during different sampling periods

\begin{tabular}{|c|c|c|c|c|c|c|c|c|c|}
\hline \multirow[b]{2}{*}{ Reservoir } & \multirow[b]{2}{*}{ Period } & \multicolumn{4}{|l|}{ Surface (0-1 m) } & \multicolumn{4}{|l|}{ Bottom (within 1 m) } \\
\hline & & Temperature $\left({ }^{\circ} \mathrm{C}\right)$ & Conductivity $\left(\mu \mathrm{S} \mathrm{cm}^{-1}\right)$ & $\mathrm{DO}\left(\mathrm{mg} \mathrm{L}^{-1}\right)$ & $\mathrm{pH}$ & Temperature $\left({ }^{\circ} \mathrm{C}\right)$ & Conductivity $\left(\mu \mathrm{S} \mathrm{cm}{ }^{-1}\right)$ & $\mathrm{DO}\left(\mathrm{mg} \mathrm{L}^{-1}\right)$ & $\mathrm{pH}$ \\
\hline \multirow[t]{3}{*}{ Cooloolabin } & Summer 2009 & 27.1 & 68 & 7.0 & 7.1 & 17.0 & 120 & 0.3 & 5.9 \\
\hline & Inflow-Summer 2011 & 27.0 & 52 & 6.0 & 6.9 & 18.7 & 94 & 0.5 & 6.5 \\
\hline & Winter 2011 & 15.2 & 73 & 6.8 & 6.9 & 15.2 & 72 & 6.7 & 6.7 \\
\hline \multirow[t]{4}{*}{ Hinze } & Summer 2005 & 29.4 & 101 & 6.9 & 8.0 & 16.7 & 115 & 0.1 & 6.1 \\
\hline & Summer 2009 & 27.2 & 102 & 7.9 & 7.9 & 16.3 & 113 & 0.1 & 6.9 \\
\hline & Inflow-Summer 2011 & 27.4 & 89 & 6.6 & 8.1 & 17.8 & 100 & 0.1 & 7.7 \\
\hline & Winter 2011 & 17.4 & 103 & 5.5 & 7.4 & 17.3 & 104 & 5.2 & 7.3 \\
\hline \multirow{4}{*}{$\begin{array}{l}\text { Leslie } \\
\text { Harrison }\end{array}$} & Summer 2005 & 29.6 & 212 & 6.2 & 7.8 & 26.5 & 227 & 1.2 & 6.5 \\
\hline & Summer 2009 & 28.3 & 247 & 6.4 & 7.1 & 27.4 & 247 & 4.4 & 6.7 \\
\hline & Inflow-Summer 2011 & 26.9 & 130 & 4.6 & 7.0 & 26.1 & 132 & 2.7 & 6.8 \\
\hline & Winter 2011 & 15.9 & 177 & 7.2 & 7.4 & 15.6 & 179 & 6.4 & 7.2 \\
\hline \multirow[t]{3}{*}{ Pocket } & Summer 2009 & 26.7 & 113 & 7.0 & 7.7 & 16.3 & 138 & 0.2 & 6.4 \\
\hline & Inflow-Summer 2011 & 24.9 & 84 & 7.0 & 8.0 & 18.3 & 102 & 0.2 & 7.8 \\
\hline & Winter 2011 & 17.1 & 116 & 5.4 & 7.5 & 17.0 & 117 & 4.4 & 7.5 \\
\hline \multirow[t]{4}{*}{ North Pine } & Summer 2005 & 28.0 & 225 & 6.1 & 8.2 & 26.3 & 241 & 0.3 & 7.1 \\
\hline & Summer 2009 & 27.4 & 283 & 7.2 & 8.0 & 24.9 & 243 & 0.8 & 7.1 \\
\hline & Inflow-Summer 2011 & 26.7 & 127 & 5.8 & 8.2 & 24.3 & 110 & 0.1 & 7.8 \\
\hline & Winter 2011 & 16.6 & 162 & 7.9 & 8.1 & 17.4 & 175 & 6.4 & 7.9 \\
\hline \multirow[t]{4}{*}{ Somerset } & Summer 2005 & 29.0 & 278 & 6.3 & 8.2 & 25.3 & 276 & 0.5 & 7.0 \\
\hline & Summer 2009 & 26.8 & 235 & 6.8 & 8.0 & 21.2 & 243 & 0.2 & 6.9 \\
\hline & Inflow-Summer 2011 & 28.8 & 124 & 7.0 & 8.8 & 23.3 & 89 & 0.4 & 7.3 \\
\hline & Winter 2011 & 16.6 & 210 & 10.5 & 8.4 & 16.2 & 214 & 7.9 & 8.2 \\
\hline \multirow[t]{4}{*}{ Wivenhoe } & Summer 2005 & 29.0 & 369 & 7.8 & 7.1 & 24.0 & 385 & 0.2 & 7.0 \\
\hline & Summer 2009 & 26.9 & 350 & 7.1 & 8.0 & 23.0 & 380 & 0.3 & 7.2 \\
\hline & Inflow-Summer 2011 & 27.6 & 248 & 7.7 & 8.6 & 24.3 & 245 & 0.8 & 8.0 \\
\hline & Winter 2011 & 16.8 & 370 & 8.4 & 8.5 & 16.6 & 374 & 7.6 & 8.4 \\
\hline
\end{tabular}


Appendix S2. Mean nutrient and suspended solids concentrations $\left(\mathrm{mg} \mathrm{L}^{-1}\right)$ of reservoirs during different sampling periods.

\begin{tabular}{|c|c|c|c|c|c|c|c|c|c|c|c|c|c|c|}
\hline \multirow[b]{2}{*}{ Reservoir } & \multirow[b]{2}{*}{ Period } & \multicolumn{7}{|c|}{ Surface (0-1 m) } & \multicolumn{6}{|c|}{ Bottom (within $1 \mathrm{~m}$ ) } \\
\hline & & $\mathrm{TN}$ & & $\mathrm{TP}$ & TSS & $\mathrm{NH}_{4}$ & $\mathrm{NO}_{2}+\mathrm{NO}_{3}$ & FRP & $\mathrm{TN}$ & TP & TSS & $\mathrm{NH}_{4}$ & $\mathrm{NO}_{2}+\mathrm{NO}_{3}$ & FRP \\
\hline \multirow[t]{3}{*}{ Cooloolabin } & Summer 2009 & & 0.36 & 0.005 & 1.8 & 0.003 & 0.001 & 0.001 & 0.92 & 0.008 & 5.8 & 0.723 & 0.011 & 0.001 \\
\hline & Inflow-Summer 2011 & & 0.31 & 0.010 & 4.1 & 0.006 & 0.005 & 0.001 & 1.31 & 0.013 & 2.5 & 1.080 & 0.004 & 0.001 \\
\hline & Winter 2011 & & 0.50 & 0.015 & 2.5 & 0.238 & 0.009 & 0.002 & 0.49 & 0.014 & 3.6 & 0.242 & 0.007 & 0.001 \\
\hline \multirow[t]{4}{*}{ Hinze } & Summer 2005 & & 0.38 & 0.014 & & 0.004 & 0.002 & 0.002 & 0.49 & 0.053 & - & 0.253 & 0.003 & 0.003 \\
\hline & Summer 2009 & & 0.30 & 0.019 & 3.0 & 0.002 & 0.001 & 0.001 & 0.29 & 0.023 & 3.8 & 0.038 & 0.048 & 0.002 \\
\hline & Inflow-Summer 2011 & & 0.50 & 0.036 & 7.8 & 0.005 & 0.006 & 0.005 & 0.38 & 0.050 & 5.5 & 0.136 & 0.013 & 0.007 \\
\hline & Winter 2011 & & 0.24 & 0.020 & 3.6 & 0.036 & 0.006 & 0.003 & 0.30 & 0.034 & 3.4 & 0.127 & 0.002 & 0.003 \\
\hline \multirow[t]{4}{*}{ Leslie Harrison } & Summer 2005 & & 0.60 & 0.027 & & 0.012 & 0.046 & 0.003 & 0.66 & 0.033 & - & 0.022 & 0.130 & 0.004 \\
\hline & Summer 2009 & & 0.49 & 0.016 & 2.5 & 0.005 & 0.002 & 0.001 & 0.51 & 0.018 & 1.0 & 0.034 & 0.013 & 0.001 \\
\hline & Inflow-Summer 2011 & & 0.87 & 0.064 & 4.5 & 0.018 & 0.123 & 0.006 & 0.88 & 0.069 & 4.3 & 0.037 & 0.141 & 0.009 \\
\hline & Winter 2011 & & 0.69 & 0.059 & 3.4 & 0.012 & 0.125 & 0.006 & 0.69 & 0.060 & 3.8 & 0.016 & 0.109 & 0.006 \\
\hline \multirow[t]{3}{*}{ Baroon Pocket } & Summer 2009 & & 0.42 & 0.019 & 2.5 & 0.003 & 0.001 & 0.002 & 0.45 & 0.049 & 4.0 & 0.261 & 0.001 & 0.004 \\
\hline & Inflow-Summer 2011 & & 0.44 & 0.041 & 7.8 & 0.006 & 0.035 & 0.004 & 0.58 & 0.076 & 19.2 & 0.185 & 0.085 & 0.018 \\
\hline & Winter 2011 & & 0.45 & 0.032 & 3.8 & 0.088 & 0.032 & 0.005 & 0.51 & 0.041 & 4.0 & 0.181 & 0.026 & 0.006 \\
\hline \multirow[t]{4}{*}{ North Pine } & Summer 2005 & & 0.56 & 0.017 & & 0.006 & 0.012 & 0.000 & 0.56 & 0.016 & - & 0.057 & 0.065 & 0.001 \\
\hline & Summer 2009 & & 0.56 & 0.026 & 1.2 & 0.002 & 0.012 & 0.003 & 0.80 & 0.046 & 7.9 & 0.157 & 0.057 & 0.006 \\
\hline & Inflow-Summer 2011 & & 0.49 & 0.042 & 14.7 & 0.008 & 0.027 & 0.005 & 0.60 & 0.064 & 44.5 & 0.145 & 0.020 & 0.004 \\
\hline & Winter 2011 & & 0.48 & 0.020 & 4.7 & 0.006 & 0.128 & 0.004 & 0.47 & 0.023 & 5.8 & 0.046 & 0.102 & 0.004 \\
\hline \multirow[t]{4}{*}{ Somerset } & Summer 2005 & & 0.55 & 0.027 & & 0.003 & 0.004 & 0.003 & 0.60 & 0.035 & - & 0.118 & 0.024 & 0.008 \\
\hline & Summer 2009 & & 0.52 & 0.027 & 2.0 & 0.002 & 0.001 & 0.002 & 1.10 & 0.116 & 5.8 & 0.602 & 0.004 & 0.013 \\
\hline & Inflow-Summer 2011 & & 0.41 & 0.047 & 10.6 & 0.037 & 0.025 & 0.009 & 0.54 & 0.090 & - & 0.105 & 0.056 & 0.027 \\
\hline & Winter 2011 & & 0.38 & 0.023 & 5.1 & 0.004 & 0.029 & 0.004 & 0.36 & 0.025 & 5.9 & 0.015 & 0.021 & 0.004 \\
\hline \multirow[t]{4}{*}{ Wivenhoe } & Summer 2005 & & 0.47 & 0.019 & & 0.000 & 0.000 & 0.000 & 0.59 & 0.028 & - & 0.167 & 0.046 & 0.012 \\
\hline & Summer 2009 & & 0.60 & 0.035 & 3.3 & 0.002 & 0.002 & 0.002 & 1.11 & 0.181 & 7.7 & 0.674 & 0.028 & 0.038 \\
\hline & Inflow-Summer 2011 & & 0.67 & 0.098 & 36.8 & 0.005 & 0.121 & 0.031 & 0.78 & 0.160 & 103.3 & 0.092 & 0.125 & 0.057 \\
\hline & Winter 2011 & & 0.53 & 0.044 & 12.3 & 0.011 & 0.140 & 0.023 & 0.49 & 0.043 & 12.7 & 0.013 & 0.128 & 0.022 \\
\hline
\end{tabular}

